Vol. 17 (2008): 252-264.

\title{
Macro- and microscale gaseous diffusion in a Stagnic Luvisol as affected by compaction and reduced tillage
}

\author{
Asko Simojoki ${ }^{*}$, Orsolya Fazekas-Becker ${ }^{2}$ and Rainer Horn ${ }^{2}$ \\ ${ }^{1}$ Department of Applied Chemistry and Microbiology, PO Box 27, FI-00014 University of Helsinki, Finland. \\ ${ }^{2}$ Institute of Plant Nutrition and Soil Science, Christian-Albrechts University, Kiel, \\ Olshausenstrasse 40, D-24107 Kiel, Germany \\ *e-mail: asko.simojoki@helsinki.fi
}

Intensification of mechanical agriculture has increased the risk for soil compaction and deformation. Simultaneously, reduced tillage practices have become popular due to energy saving and environmental concerns, as they may strengthen and improve the functioning of structured soil pore system. Soil aeration is affected by both compaction and reduced tillage through changes in soil structure and in the distribution of easily decomposable organic matter. We investigated whether a single wheeling by a $35000 \mathrm{~kg}$ sugar-beet harvester in a Stagnic Luvisol derived from loess near Göttingen, Germany, influenced the gas transport properties (air permeability, gaseous macro- and microdiffusivities, oxygen diffusion rate) in the topsoil and subsoil samples, and whether the effects were different between long-term reduced tillage and mouldboard ploughing. Poor structure in the topsoil resulted in slow macro- and microscale gas transport at moisture contents near field capacity. The macrodiffusivities in the topsoil under conventional tillage were slower compared with those under conservation treatment, and soil compaction reduced the diffusivities by about half at the soil depths studied. This shows that even one pass with heavy machinery near field capacity impairs soil structure deep into the profile, and supports the view that reduced tillage improves soil structure and aeration compared with ploughing, especially in the topsoil.

Key-words: soil structure, compaction, reduced tillage, ploughing, aeration, gaseous diffusivity 
Vol. 17 (2008): 252-264.

\section{Introduction}

Two opposing major trends dominate soil management in present mechanized agriculture. Economic pressures lead to more intense production with bigger and heavier machines on ever fewer and larger farms. This will increase the risk of a more intense subsoil compaction in the future, even if reduced ground contact pressure at an identical mass are less harmful for soil structure (Peth et al. 2006). On the other hand, the needs to cut energy costs and to promote soil carbon sequestration and erosion control due to global warming and environmental concerns will favour reduced tillage over conventional mouldboard ploughing. Soil compaction and reduced tillage both affect soil aeration by changing the amount and continuity of air-filled pores, and the distribution of easily decomposable organic matter in the soil (Soane and van Ouwerkerk 1994).

The concerns about soil compaction are widespread (Horn et al. 2000, Pagliai and Jones 2002, Horn et al. 2006). In general, wheeling that produces mechanical stresses exceeding the internal soil strength causes compaction and shear processes that deteriorate aggregates, resulting in a more complete homogenization of soil structure even at high bulk densities. The consequently impaired aeration may cause poor plant growth and increased emissions of gases and nutrients to the environment. Compaction may also temporarily increase soil respiration rates, as the organic matter protected within the aggregates is exposed for microbial decomposition. In the subsoil, compaction remains effective for decades, as the structure forming processes are slow and the management techniques are inefficient. Still, the extent to which the results on uniaxial soil compaction in the laboratory or those on the homogeneous compaction of experimental fields apply to normal farming is occasionally questioned (Schäfer-Landefeld et al. 2004, Koch et al. 2005), although many researchers validated them in situ (Peth et al. 2006, Richards et al. 2000).

Mouldboard ploughing produces a more homogeneous ploughed layer and a tortuous pore system in comparison to conservation tillage that allows, in principle, the development of a more heterogeneous, stronger, and continuous pore system deeper into the soil. Simultaneously, however, the organic matter accumulating near soil surface increases the risk for anoxic microsites. Ploughing is often claimed better for soil aeration compared with reduced tillage. However, the results on this are contradictory (Ball et al. 1994, Schjønning and Rasmussen 2000).

In this study, we aimed to investigate whether one-pass wheeling by a modern sugar beet harvester in the field influences gas transport in a Stagnic Luvisol derived from loess, and whether the effects were different between long-term conservation (=mulch) and conventional tillage. We measured the effects on gas transport by a robust set of variables at macro- and microscale (water retention, air permeability, gaseous diffusivity, oxygen diffusion rate, oxygen partial pressures, gas emissions) in samples taken from several depths in the soil.

\section{Material and methods}

\section{Site description}

The experimental field was part of a larger field experiment in Harste, about $8 \mathrm{~km}$ from the city of Göttingen in the Lower Saxony, Germany, as described in detail by Fazekas (2005). The field was setup and managed by the Institute for Sugar Beet Research (IfZ) in Göttingen. The soil was classified as Stagnic Luvisol derived from loess with a texture of silt loam (silt $85 \%$, clay $12 \%$, sand $3 \%$ ). The Ap horizon was characterized by a polyhedral or crumbly structure ( $4 \%$ organic $C)$. The subsoil at the plough pan was characterized by a platy $(0.6 \%$ organic $C)$ and in deeper horizons by a platy/polyhedral structure $(0.5 \%$ organic $\mathrm{C})$ in both tillage treatments.

Until 1992 the whole field was ploughed till $30 \mathrm{~cm}$. Since 1992, the experimental plots were subjected annually either to mouldboard ploughing to a depth of $30 \mathrm{~cm}$ (termed here "ploughed = conventionally tilled soil") or to the reduced tillage by a cultivator to depth of $8-10 \mathrm{~cm}$ (termed here 
Simojoki, A. et al. Gaseous diffusion in a loess soil

"conservation mulched soil"). The crop rotation included winter wheat, winter barley, sugar beet and mustard. Harvesting was carried out by a oneor two-rowed sugar beet harvester (a total mass of $7000 \mathrm{~kg}$ ) and a combine harvester (c. $15000 \mathrm{~kg}$ ). In order to simulate the influence of heavier harvesters more often in use nowadays, selected plots were additionally compacted by one-pass wheeling with a $35000 \mathrm{~kg}$ six-row sugar beet harvester (Holmer Terra Dos) since 2001.

\section{Sampling}

A total of 36 structurally undisturbed soil samples were taken for gaseous measurements at three depths in one replicate block of the field after harvest of the beets. Three soil samples were taken in vertical direction from each experimental treatment into three $236 \mathrm{~cm}^{3}$ (height $3 \mathrm{~cm}$, diameter $10 \mathrm{~cm}$ ) stainless-steel cylinders at 12, 35 and $60 \mathrm{~cm}$ depths. The $12 \mathrm{~cm}$ sampling depth was just below the chiselled layer of conservation plots. One sample was later lost by accident. In addition, six structurally undisturbed samples were taken from each plot and layer of all four replicate blocks into $100 \mathrm{~cm}^{3}$ (height $4 \mathrm{~cm}$, diameter $5.6 \mathrm{~cm}$ ) stainless-steel cylinders for the water retention measurements as a part of soil mechanical investigations by Fazekas (2005).

The uncompacted samples were sampled on 10 November 2003, and the compacted plots immediately after the wheeling by a $35000 \mathrm{~kg}$ sugar-beet harvester on 17 November 2003. Until the beginning of the measurements in Spring 2004, the soil cylinders were stored in small acrylic containers, enclosed in a plastic bag together with moist tissue paper to prevent soil drying, and kept at about $20^{\circ} \mathrm{C}$ room temperature.

\section{Outline of the measurements}

In this study, we determined the oxygen diffusion rate (ODR), the gaseous macro- and microdiffusivities of $\mathrm{O}_{2}$, and the air permeability in the $236 \mathrm{~cm}^{3}$ soil samples after equilibrating water-saturated samples at matric potentials $-30 \mathrm{hPa},-60 \mathrm{hPa}$ and $-150 \mathrm{hPa}$. Drying of soil and the consequent changes in air-filled porosity during the measurements were monitored by weighing the samples regularly. The original idea of measuring all the variables in all samples after equilibration to the target values could not be realized. Instead, the first measurement round was carried out after equilibrating one sample of each treatment and soil depth at one of the target values. A second round of measurements was carried out after equilibrating all samples at $-30 \mathrm{hPa}$. However, evaporation decreased the matric potential during the measurements: at the time of macrodiffusivity measurements it was about $-60 \mathrm{hPa}$ with the mean values of $-64 \pm 7,-46 \pm 3$ and $-45 \pm 2 \mathrm{hPa}$ (mean \pm standard error) in the soil samples taken at 12 , $35,60 \mathrm{~cm}$ depths, respectively, with no significant differences between the experimental treatments (Table 2). The $\mathrm{O}_{2}$ partial pressure microprofiles in the soil, and the gas emission rates $\left(\mathrm{O}_{2}, \mathrm{CO}_{2}, \mathrm{~N}_{2} \mathrm{O}\right.$, $\mathrm{CH}_{4}$ ) from the soil, determined for each sample before the diffusion measurements and at the end of experiment, respectively, will be reported in another paper (in preparation).

\section{Soil water retention and air-filled porosity}

Drying curves of soil water retention were determined by first saturating the samples with water and then allowing the samples to dry to different matric suctions. The $236 \mathrm{~cm}^{3}$ samples were equilibrated to matric potentials $0,-30,-60$ or $-150 \mathrm{hPa}$ on a sand box or a ceramic plate. A few additional points of water retention were obtained by gravimetry and microtensiometry (tip diameter $0.5 \mathrm{~mm}$ ) during the gas transport measurements. Soil water retention in the $100 \mathrm{~cm}^{3}$ samples were determined at $0,-10,-20$ and $-30 \mathrm{hPa}$ on a sand box, at $-60,-150$ and -300 $\mathrm{hPa}$ on ceramic plates, and that at $-1.5 \mathrm{MPa}$ from disturbed samples by a pressure plate apparatus (Fazekas 2005). The - 10 and $-20 \mathrm{hPa}$ matric potential data for the $100 \mathrm{~cm}^{3}$ samples were excluded from the estimation of water retention curves. Waterretention curves were estimated individually for 
Vol. 17 (2008): 252-264.

each of $236 \mathrm{~cm}^{3}$ soil sample, and using plotwise averaged data at a given matric water potential for the smaller samples for each treatment and depth in the field. The average van Genuchten parameter values (van Genuchten 1980) summed up in Table 1 are based on all data in each treatment fitted with the equation

$S=\frac{\left(\theta-\theta_{r}\right)}{\left(\theta_{s}-\theta_{r}\right)}=\left(1-\frac{1}{1+\alpha\left|\psi_{m}\right| N}\right)^{M}$, where

$\theta, \theta_{\mathrm{s}}, \psi_{\mathrm{m}}$ and $\mathrm{S}$ are the actual and saturated volumetric water contents, the matric potential, and the effective degree of saturation, respectively. This approach is well established and widely used for describing water retention in unsaturated soils since 1980 . The estimation was carried out assuming Mualem specification $\mathrm{M}=1-1 / \mathrm{N}$, zero residual water content $\theta_{\mathrm{r}}=0$, and air-filled porosity $\varepsilon_{\mathrm{a}}=\theta_{\mathrm{s}}-\theta$.

\section{Oxygen diffusion rate}

Oxygen diffusion rate was measured polarographically by a meter (ODR-OWH-02, Holmqvist Electromechanics, Vantaa, Finland) controlling the effective polarization by a 3-electrode method (Malicki and Walczak 1983). Four bare-tipped Pt-electrodes (diameter $0.65 \mathrm{~mm}$, length $4 \mathrm{~mm}$ ) were inserted into soil from the surface. The $\mu \mathrm{A}$-currents after 5 minutes of polarization were converted to ODR values $\left(\mu \mathrm{g} \mathrm{m}^{2} \mathrm{~s}^{-1}\right)$ by a factor of 9.75 .

\section{Gaseous macro- and microdiffusivities}

The macrodiffusivity of $\mathrm{O}_{2}$ in soil was determined with a two-chamber system built for the purpose after Ball et al. (1981). The soil cylinder was fastened

Table 1. Parameters of water retention curves for soil samples as related to the experimental treatments and soil depth.

\begin{tabular}{llllllll}
\hline$\theta_{\mathrm{s}}(\mathrm{SE})$ & $\alpha(\mathrm{SE})$ & $\mathrm{N}(\mathrm{SE})$ & $\mathrm{R}^{2}$ & $\theta_{\mathrm{s}}(\mathrm{SE})$ & $\alpha(\mathrm{SE})$ & $\mathrm{N}(\mathrm{SE})$ & $\mathrm{R}^{2}$ \\
Treatment \\
Depth,cm
\end{tabular}

Samples $236 \mathrm{~cm}^{3}$

Ploughed, uncompacted

$\begin{array}{lllll}12 & 0.398(0.011) & 0.019(0.013) & 1.154(0.027) & 0.931\end{array}$

$\begin{array}{llllll}35 & 0.397(0.008) & 0.088(0.042) & 1.121(0.013) & 0.949\end{array}$

$\begin{array}{llllll}60 & 0.410(0.008) & 0.073(0.029) & 1.138(0.014) & 0.956\end{array}$

Ploughed, compacted

$\begin{array}{lllll}12 & 0.399(0.008) & 0.009(0.005) & 1.187(0.030) & 0.961\end{array}$

$\begin{array}{llllll}35 & 0.417(0.006) & 0.114(0.038) & 1.113(0.009) & 0.971\end{array}$

$\begin{array}{llllll}60 & 0.419(0.009) & 0.053(0.021) & 1.149(0.016) & 0.961\end{array}$

Mulched, uncompacted

$\begin{array}{lllll}12 & 0.406(0.006) & 0.017(0.005) & 1.168(0.015) & 0.970\end{array}$

$\begin{array}{llllll}35 & 0.409(0.006) & 0.057(0.016) & 1.129(0.010) & 0.974\end{array}$

$\begin{array}{llllll}60 & 0.399(0.008) & 0.040(0.017) & 1.145(0.016) & 0.956\end{array}$

Mulched, compacted

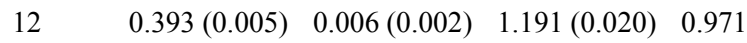

$\begin{array}{llllll}35 & 0.393(0.007) & 0.026(0.010) & 1.150(0.015) & 0.965\end{array}$

$\begin{array}{lllll}60 & 0.405(0.007) & 0.042(0.015) & 1.144(0.013) & 0.972\end{array}$
Samples $100 \mathrm{~cm}^{3}$

$0.404(0.005) \quad 0.006(0.001) \quad 1.214(0.014) \quad 0.983$

$\begin{array}{lllll}0.425(0.011) & 0.061(0.031) & 1.114(0.012) & 0.934\end{array}$

$\begin{array}{lllll}0.404(0.010) & 0.020(0.009) & 1.141(0.016) & 0.947\end{array}$

$0.397(0.003) \quad 0.003(0.001) \quad 1.240(0.012) \quad 0.993$

$\begin{array}{lllll}0.423(0.009) & 0.040(0.015) & 1.123(0.010) & 0.961\end{array}$

$\begin{array}{llll}0.394(0.008) & 0.018(0.008) & 1.147(0.015) & 0.961\end{array}$

$0.402(0.006) \quad 0.008(0.002) \quad 1.195(0.014) \quad 0.978$

$\begin{array}{llll}0.412(0.009) & 0.026(0.010) & 1.147(0.014) & 0.963\end{array}$

$\begin{array}{lllll}0.408(0.008) & 0.021(0.007) & 1.155(0.013) & 0.969\end{array}$

$0.398(0.003) \quad 0.004(0.001) \quad 1.227(0.010) \quad 0.994$

$\begin{array}{lllll}0.406(0.009) & 0.019(0.008) & 1.151(0.015) & 0.959\end{array}$

$\begin{array}{llll}0.398(0.006) & 0.012(0.003) & 1.169(0.012) & 0.979\end{array}$

Van Genuchten parameters $\theta_{\mathrm{s}}$, $\alpha$ and N (SE standard error) with $\theta_{\mathrm{r}}=0, \mathrm{M}=1-1 / \mathrm{N}$. The coefficient of determination $\mathrm{R}^{2}$. 


\section{AGRICULTURAL AND FOOD SCIENCE}

Simojoki, A. et al. Gaseous diffusion in a loess soil

air-tight between two aluminium chambers capped at both ends by Perspex plates joined together by threaded metal rods. Luer-connectors and threeway valves by medical industry provided the gas inlet and outlet. Medium-soft neoprene plates and O-rings sealed the soil cylinder and the end plates, respectively. The $\mathrm{O}_{2}$ sensors were inserted through butyl rubber septa in the side-wall or upper plate of chambers. A 1-mm mesh plastic net was secured below the sample to protect the electrode. Leaks were controlled routinely by a pneumatic test $(+8$ $\mathrm{hPa}$ ) before the measurements.

First, the lower chamber was flushed with $\mathrm{N}_{2}$ gas and the upper one with compressed air. Then, the valves were closed. The diffusivity was calculated from the dimensions of equipment and the rate of decrease in $\mathrm{O}_{2}$ concentration difference between upper and lower chambers with time (Ball et al. 1981), and expressed as relative diffusivity with respect to pure air. The latter was approximated by an empirical function given by Marrero and Mason (1972).

The oxygen partial pressures were measured by polarographic Clark-type microelectrodes producing picoampere range current proportional to the $\mathrm{O}_{2}$ partial pressure. A two-point calibration was carried out in water-saturated air (c. $21 \mathrm{kPa} \mathrm{O}_{2}$ ) and $\mathrm{N}_{2}$ bubbled water (zero $\mathrm{O}_{2}$ ). The laboratory temperature was continuously monitored by two Pt100 temperature sensors to compensate for the impact of any temperature fluctuations with time (nominal sensitivity $2 \% \mathrm{~K}^{-1}$ ). Any other temporal drift in the sensor response was assumed linear between consecutive calibrations. The sensors had a tip diameter of $100 \mu \mathrm{m}(\mathrm{Ox} 100 \mathrm{u}$, Unisense $\mathrm{A} / \mathrm{S}$, Aarhus, Denmark). The current was measured by a commercial 2-channel picoammeter (PA2000, Unisense), a device provided by Jaissle Elektronik $\mathrm{GmbH}$, Waiblingen (Neustadt), a picoammeter constructed by the earlier research projects of CAU, and two old nanoammeters (Knick) with self-made polarization units.

Before starting the macrodiffusivity measurement, the microdiffusivity of $\mathrm{O}_{2}$ in soil was determined for each sample from the rate of attenuation with soil depth of the periodic fluctuation of $\mathrm{O}_{2}$ concentration applied at the surface after Rappoldt
(1995). In brief, one microelectrode was kept in the upper chamber ("surface electrode") and the tip of another ("soil electrode") was manually lowered into the soil by a micromanipulator. Aluminium foil covered the space between the electrode shaft and the chamber lid. The gas flux through the upper chamber was alternated cyclicly between compressed air and $\mathrm{N}_{2}$ at 5-minute intervals by a three-way valve with a programmable timer (Bürkert 1078-2). The electrode was lowered by $0.5 \mathrm{~mm}$ or 1-mm increments at 1-hour intervals to the soil depth of $2.5 \mathrm{~mm}$ or $5.0 \mathrm{~mm}$, respectively. The first cycle at each depth was excluded from the data due to irregularities.

The $\mathrm{O}_{2}$ microdiffusivity was calculated from the rate of change of phase shift between the surface and soil electrodes with depth (Rappoldt 1995). For that purpose, the $\mathrm{O}_{2}$ signals were expressed as Fourier series and the phase shifts were calculated for each harmonic component separately. The apparent diffusivity $\left(D^{*}\right)$ was estimated from

$\varphi_{n}(x)=x \sqrt{n} / d=x \sqrt{n} / \sqrt{2 D^{*} / \omega} \quad$,

where $\varphi_{\mathrm{n}}$ is the phase shift, $\mathrm{x}$ is the depth, $\mathrm{d}$ and $\omega$ are the damping depth and angular frequency of the first harmonic $(n=1)$, respectively. The data was occasionally very irregular. The steepest slope of phase shift with depth as judged by eye was then used for the estimation. The apparent diffusivity was converted to the effective microdiffusivity $\left(\mathrm{D}_{\text {mic }}\right)$ by multiplying it with the estimated porosity of waterfilled volume in unsaturated soil $\left(\theta_{\mathrm{su}}=\left(\theta_{\mathrm{s}}-\varepsilon_{\mathrm{a}}\right) /\right.$ $\left(1-\varepsilon_{\mathrm{a}}\right)$ ), and to the relative microdiffusivity $\left(\mathrm{D}_{\text {mic }} /\right.$ $\mathrm{D}_{\mathrm{w}}$ ) by dividing this by the $\mathrm{O}_{2}$ diffusivity in pure water $\left(D_{w}\right)$ approximated by a function given by Choy and Reible (2000). Values indicating diffusivities in soil water-filled pores larger than those in pure water were excluded as physically unrealistic.

\section{Air permeability}

The air permeability was determined from the volumetric flow rate through samples by a steady- 
Vol. 17 (2008): 252-264.

state method (Ball and Smith 2001) at a constant $1 \mathrm{hPa}$ pressure gradient. In a few cases, a pressure gradient of $10 \mathrm{hPa}$ was used to increase the flow rate to measurable values.

\section{Data acquisition}

The output voltage of ammeters and the resistance of Pt100 sensors were logged at $10 \mathrm{~s}$ intervals by a multi-channel data logger. The data were downloaded to a PC and converted to a text file (DL2e Logger PC Software, Delta-T devices Ltd, England) for later processing by statistical programs. Outside the actual measurement periods, background data were logged at 1-minute intervals as needed.

\section{Statistical analysis}

The significance of treatment effects as well as differences between treatment means and more general contrasts were examined by the analysis of variance and covariance, Tukey's test and Brown and Forsythe's method $(p<0.05)$. It is noted that the replicates of larger soil samples $\left(236 \mathrm{~cm}^{3}\right)$ were taken from same plot and are thus not true replicates of treatments in the field but represent only one block. In contrast, the water-retention data on smaller cylinders represent the whole field. All data processing was carried out in a general computing environment Survo MM (see www.survo.fi/english).

\section{Results}

\section{Macroscale gas transport in the soil}

The water retention curves indicated slight differences between the experimental treatments (Table 1). In contrast, the topsoil (12 cm depth) differed clearly from the subsoil. The smaller values of parameter $\alpha$ in topsoil compared with subsoil indicate that, in a drying soil, air enters the topsoil at more negative matric potentials, or at smaller equivalent pore radius compared with the deeper soil layers. According to the water retention data, the air-filled porosities were about $2 \%$ and $5 \%$ at $-30 \mathrm{hPa}$ matric potential, and about $5 \%$ and $7-8 \%$ at $-60 \mathrm{hPa}$ matric potential, in the topsoil and deeper soil layers, respectively. The differences in water retention by different soil layers were also confirmed by the measurements with smaller soil samples. Nevertheless, the parameter $\alpha$ was consistently lower for the smaller soil samples than for the larger ones. The smaller samples were taken representatively from the whole field, whereas the larger ones represented only one replicate block in the field. The reason for the difference was however not due to the field-scale variation, but rather the sample size as such, as similar differences were observed also in the particular field block from where the larger samples were taken (not shown).

In the ploughed topsoil, the relative gaseous macrodiffusivity and the air permeability were clearly lower than those in the mulched soil and those deeper in the ploughed soil (Table 2). The topsoil contained less air than the deeper soil layers. Unlike the diffusivity and the permeability, the air-filled porosity at different layers did not depend significantly on the tillage treatment.

The relationship between the relative diffusivity and soil air-filled porosity could be described by a log-linear regression (Fig. 1). In very wet soil, the diffusivity approached values close to those in water. The analysis of covariance did not indicate differences in the regressions between the experimental treatments (not shown). Further analysis with regression-corrected diffusivity values (= comparisons at the same air-filled porosity) in essence confirmed the same significant differences between the treatments as in Table 2 (not shown).

\section{Gaseous diffusivities predicted based on the soil-water characteristic}

In order to improve the generality of the results obtained with $236 \mathrm{~cm}^{3}$ soil samples, we established 
Simojoki, A. et al. Gaseous diffusion in a loess soil

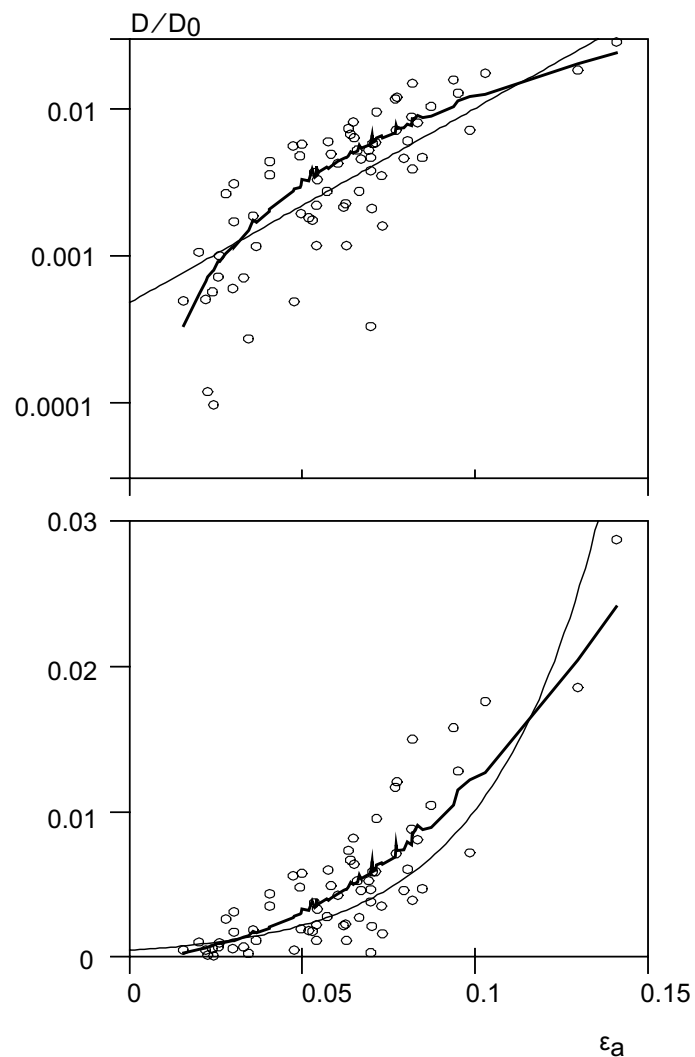

Figure 1 Relative gas diffusivity $\left(\mathrm{D} / \mathrm{D}_{0}\right)$ as related to the air-filled porosity $\left(\varepsilon_{\mathrm{a}}\right)$. Note the logarithmic and linear ordinate scales in the upper and lower graph, respectively. The thin lines represent the regression $\ln \mathrm{D} / \mathrm{D}_{0}=$ $-7.65+30.6 \varepsilon_{\mathrm{a}}$ obtained by the analysis of covariance $\left(\mathrm{R}^{2}\right.$ $=0.84$ for the model). The thicker curves represent the diffusivities predicted by the modified 3POE-vG diffusivity model (with $\mathrm{m}=1.66$, see the text). a regression of relative macrodiffusivity on air-filled porosity and water-retention parameters in the soil, and applied it to predict the diffusivities based on the more representative set of samples taken into $100 \mathrm{~cm}^{3}$ cylinders. As the diffusion depends strongly on soil structure, and as we had observed structural differences between large and small samples in the water-retention properties (Table 1), direct use of the regression obtained with the larger samples seemed inappropriate for the smaller ones. Instead, we modified slightly the diffusivity model by Moldrup et al. (2005) to predict the diffusivity based on the measured water-retention data.

The relative diffusivity can be written after the 3POE model by Moldrup et al. (2005) as

$$
D / D_{0}=\Phi^{m}\left(\frac{\boldsymbol{\varepsilon}_{a}}{\boldsymbol{\Phi}}\right)^{X_{100}}, \text { where } X_{100}=m+\frac{\log \left(\varepsilon_{100}\right)^{1 / 4}}{\log \left(\boldsymbol{\varepsilon}_{100} / \Phi\right)}
$$

and $\varepsilon_{100}$ is the air-filled porosity at $-100 \mathrm{hPa}$ matric suction and $\Phi$ is the total porosity. On the other hand, $D / D_{0}$ can be written in terms of the effective degree of saturation $S=\left(\theta-\theta_{\mathrm{r}}\right) /\left(\theta_{\mathrm{s}}-\theta_{\mathrm{r}}\right)$ and van Genuchten water-retention parameters by assuming $\Phi=\theta_{\mathrm{s}}, \varepsilon_{\mathrm{a}}=\left(\theta_{\mathrm{s}}-\theta\right)=\left(\theta_{\mathrm{s}}-\theta_{\mathrm{r}}\right)(1-\mathrm{S})$ and Mualem specification $\mathrm{M}=1-1 / \mathrm{N}$ (3POE-vG model, Moldrup et al. 2005)

$$
\begin{aligned}
& D / D_{0}=\theta_{s}^{m}\left(\frac{\left(\theta_{s}-\theta_{r}\right)(1-S)}{\theta_{s}}\right)^{X_{100}}= \\
& \theta_{s}^{\left(m-X_{100}\right)}\left(\left(\theta_{s}-\theta_{r}\right)\left(1-\frac{1}{1+\alpha|\psi|^{N}}\right)^{(1-1 / N)}\right)^{X_{100}}
\end{aligned}
$$

\begin{tabular}{|c|c|c|c|c|c|c|c|}
\hline \multirow[t]{2}{*}{$\begin{array}{c}\text { Depth, } \\
\mathrm{cm}\end{array}$} & \multicolumn{2}{|c|}{$\begin{array}{c}\text { Relative } \\
\text { macrodiffusivity } \\
D / D_{0} \times 10^{3}\end{array}$} & \multirow[t]{2}{*}{$\begin{array}{c}\text { Relative } \\
\text { microdiffusivity } \\
D_{\text {mic, },} / D_{0, \mathrm{w}}\end{array}$} & \multirow[t]{2}{*}{$\begin{array}{c}\text { Air-filled } \\
\text { porosity } \\
\varepsilon_{\mathrm{a}} \\
\end{array}$} & \multicolumn{2}{|c|}{$\begin{array}{c}\text { Air } \\
\text { permeability } \\
k_{\mathrm{a}} / \mu \mathrm{m}^{2}\end{array}$} & \multirow[t]{2}{*}{$\begin{array}{c}\text { Oxygen } \\
\text { diffusion rate } \\
\text { ODR } / \mu \mathrm{g} \mathrm{m}^{-2} \mathrm{~s}^{-1}\end{array}$} \\
\hline & Mulch & Ploughed & & & Mulch & Ploughed & \\
\hline 12 & $1.01^{\mathrm{b}}$ & $0.23^{\mathrm{a} *}$ & $0.19^{a}$ & $0.030^{\mathrm{a} *}$ & $5^{b}$ & $0.6^{\mathrm{a}}$ & $25^{\mathrm{a}}$ \\
\hline 35 & $3.61^{b c}$ & $2.68^{\mathrm{bc}}$ & $0.44^{\mathrm{b}}$ & $0.060^{\mathrm{b}}$ & $12^{\mathrm{b}}$ & $11^{\mathrm{b}}$ & $31^{\mathrm{a}}$ \\
\hline 60 & $2.85^{\mathrm{bc}}$ & $6.32^{\mathrm{c}}$ & $0.34^{\mathrm{b}}$ & $0.060^{\mathrm{b}}$ & $9^{b}$ & $24^{\mathrm{b}}$ & $20^{\mathrm{a}}$ \\
\hline $\mathrm{n}$ & 6 & $6^{*}$ & 7 & $12^{*}$ & 6 & 6 & 12 \\
\hline
\end{tabular}

Table 2 Relative gaseous macro- and microdiffusivities, air-filled porosity, air permeability, and oxygen diffusion rate in soil as related to tillage treatments and soil depth.

$\mathrm{n}=$ the number of replicates (the means denoted by ${ }^{*}$ miss one replicate sample). The values represent averages over compaction levels, as compaction effects were not significant by ANOVA $(p>0.05)$. The measurements were carried out after equilibrating the samples at $-30 \mathrm{hPa}$ matric potential. Due to evaporation during the measurements, the matric potential at the time of macrodiffusivity measurements was about $-60 \mathrm{hPa}$. Significant differences are indicated by different letters $(p<0.05)$. $\mathrm{D} / \mathrm{D}_{0}$ was tested with log-transformed data. 
Vol. 17 (2008): 252-264.

Table 3 Estimated ${ }^{*} \mathrm{D} / \mathrm{D}_{0}$ and $\varepsilon_{\mathrm{a}}$ mean values at $-60 \mathrm{hPa}$ matric potential at different soil depths ${ }^{\#}$, and the mean values before and after soil compaction ${ }^{\dagger}$.

\begin{tabular}{llcc}
\hline $\begin{array}{l}\text { Depth, } \\
\mathrm{cm}\end{array}$ & & $\begin{array}{c}\text { Relative mac- } \\
\text { rodiffusivity } \\
\mathrm{D} / \mathrm{D}_{0} \times 10^{3}\end{array}$ & $\begin{array}{c}\text { Air-filled } \\
\text { porosity } \\
\varepsilon_{\mathrm{a}}\end{array}$ \\
\hline 12 & & $0.65^{\mathrm{a}}$ & $0.024^{\mathrm{a}}$ \\
35 & $4.70^{\mathrm{b}}$ & $0.065^{\mathrm{c}}$ \\
60 & & $2.90^{\mathrm{b}}$ & $0.049^{\mathrm{b}}$ \\
$12-60$ & $\begin{array}{l}\text { Before } \\
\text { compaction }\end{array}$ & $2.76^{\mathrm{b}}$ & $0.051^{\mathrm{a}}$ \\
& $\begin{array}{l}\text { After } \\
\text { compaction }\end{array}$ & $1.54^{\mathrm{a}}$ & $0.041^{\mathrm{a}}$ \\
\hline
\end{tabular}

$\mathrm{n}=16$ the number of replicates at each soil depth. Significant differences between soil depths or compaction levels are indicated by different letters $(p<0.05)$. D/ $\mathrm{D}_{0}$ was tested with logtransformed data.

* Estimated by the modified 3POE-vG model and measured water retention data.

\# Across the tillage and compaction levels at different depths

${ }^{\dagger}$ Across all depths before and after a single pass of a $35000 \mathrm{~kg}$ sugar-beet harvester. The effects of tillage and the interaction of compaction and soil depth not significant by ANOVA $(p>0.05)$.

These formulations are equivalent, if $\varepsilon_{100}$ is estimated by using the van Genuchten parameters. Moldrup et al. (2005) derived the equations with $\mathrm{m}=2$ in accordance with the classical Buckingham model in dry soil. Our modification was to introduce the parameter $m$.

In this study, $\mathrm{m}=1.66$ gave the best fit with the data (Figure 1). The model was then used for predicting gaseous diffusivities based on the soilwater characteristics of smaller samples. Very low diffusivity values were predicted in the topsoil at $-60 \mathrm{hPa}$ matric potential (Table 3) in accordance with the direct results (Table 2). However, the interaction between the tillage treatments and soil depth was not confirmed, as the predicted values at a given depth in the ploughed and mulched soils were roughly similar. In contrast, the effect of compaction was apparent in this larger data set. Compaction decreased air-filled porosities non-significantly but reduced the estimated diffusivities almost by half, roughly similarly at all soil depths (Table 3). Moreover, the same significant differences between experimental treatments and soil depth were confirmed with several traditional diffusivity models, such as those attributed to Buckingham, Penman and Millington-Quirk, although the magnitude of predicted values varied widely depending on the model (data not shown).

\section{Microscale gas transport in the soil}

The microdiffusivity was smaller in the topsoil than deeper in the soil (Table 2), as confirmed by the significant contrast between $12 \mathrm{~cm}$ soil depth against the other depths (Brown and Forsythe's method, $p<0.05)$. This result is similar to that for the macrodiffusivity. However, the microdiffusivity was not significantly affected by the tillage and compaction treatments.

The oxygen diffusion rates were, on the average, 20-30 $\mu \mathrm{g} \mathrm{m}^{-2} \mathrm{~s}^{-1}$, and did not show any significant effects of experimental treatments and soil depth (Table 2). ODR values were notably more variable than the microdiffusivity data. This may be partly caused by the fact that we did not exclude any ODR data on the grounds of being physically unrealistic.

\section{Discussion}

\section{The effects of conventional or conserva- tion tillage and compaction on soil gas transport properties}

The soil in this study is characterized by a weak structure in the A horizon under conventional and by an improving aggregate formation under conservation tillage, but in both cases the topsoil still showed small values of air-filled porosities and correspondingly low gaseous diffusivities and air permeabilities at matric potentials near the field capacity. The platy structure dominant in the plough pan and deeper soil layers impairs strongly the gas 


\section{AGRICULTURAL AND FOOD SCIENCE}

Simojoki, A. et al. Gaseous diffusion in a loess soil

transport in the vertical direction, so that at field capacity the horizontal fluxes are generally much higher than the vertical ones (Dörner and Horn 2006). However, where this effect is counteracted and obscured by any vertical macropores and cracks in the soil (Dörner and Horn 2006), the horizontal fluxes may only be about half of the vertical ones (Fazekas 2005). The low vertical air permeabilities reported in this paper thus overestimate the horizontal ones. Gas transport is slower in the topsoil than in the subsoil no doubt not only due to textural differences, but also due to the past tillage operations (conservation or conventional) in the surface horizon. Furthermore, Kirby (1991) reported reduction of air permeabilities in the top soil due to wheeling. Tire slip causes not only vertical compaction but the pores will also be sheared.

Smaller measured values of gaseous diffusivity and air permeability in the ploughed topsoil compared with the mulched topsoil demonstrate the detrimental effects of annual mouldboard ploughing on the structure and gas transport properties of soils. On the other hand, the predictions by the water-characteristic coupled gaseous diffusivity model indicate that one-pass compaction with the sugar-beet harvester nearly halves the gaseous diffusivities at the soil depths studied. Both of these main conclusions rely on assumptions that not fully ascertained within our study.

As soil sampling for actual gas transport measurements was limited to only one replicate block in the field, potential spatial variation of soil may have confounded the data. The negligible differences (similar within 1\%) between the error variance in the actually measured diffusivities and that in the larger model-predicted data set representing the whole field, as well as the non-significant effects of blocking, moderate these concerns. Nevertheless, the effects of compaction on the air-filled porosity were smallest in this very block and this may well have contributed to the lack of significant effects of compaction on the actually measured gas transport variables in that block, contrary to the significant effects found with the model-predicted values.

On the other hand, the model predictions of gaseous diffusivity are restricted by any inabil- ity of the model to relate the diffusivity to other measurements on soil structure. The analysis of variance with the predicted values in the samples used for actual measurements revealed only part of the significant treatment effects observed with actual measurements (only the main effect of soil depth significant; data not shown). Even a modern and very sophisticated gaseous diffusivity model thus could not take into adequate account of all relevant structural features of soil in this study. As a consequence, the observed significant differences between conventional and reduced tillage may well be real, even if not confirmed by the larger modelpredicted data.

Based on the above discussion, we consider our conclusions about the detrimental effects of conventional ploughing and heavy compaction on the macroscale gas transport in soil as the most likely explanations based on the available information. Nevertheless, new experimentation and empirical data on the topic are needed to confirm or reject the validity of our results in a wider range of soil and environmental conditions.

The measured air-filled porosities of less than $10 \%$ by volume at matric potentials near the field capacity in this study indicate deficient aeration (Stepniewski et al. 1994). Moreover, the gaseous diffusivities in the topsoil were below the $\mathrm{D} / \mathrm{D}_{0}$ values in the range $0.00075-0.005$ cited by Stepniewski et al. (1994) as lower critical aeration limits for plant growth. The air permeabilities $\left(0.5-24 \mu \mathrm{m}^{2}\right.$, or $0.4-15 \mu \mathrm{m} \mathrm{s}^{-1}$ as air conductivities) were in the middle range of common values in soil (0.01-500 $\mu^{2}$ ) according to Stepniewski et al. (1994). However, according to the classification of European soils with respect to compaction prevention (Horn et al. 2005), the values in the topsoil are very low $\left(<5.5 \mu \mathrm{m} \mathrm{s}^{-1}\right)$, and those in the other layers are low (5.5-12 $\mu \mathrm{m} \mathrm{s}^{-1}$; except for the medium high permeability in the ploughed soil at $60 \mathrm{~cm}$ ).

In a like manner with the macrodiffusivities, the topsoil values of microdiffusivities were smaller than those deeper in the soil. The relative microdiffusivities in this study were close to that obtained by the same method in water-saturated soil (Rappoldt $1995, \mathrm{D} / \mathrm{D}_{0, \mathrm{w}}=\mathrm{D} \theta_{\mathrm{s}} / \mathrm{D}_{0, \mathrm{w}}=0.4 \times 0.36 \times 10^{-9}$ $\mathrm{m}^{2} \mathrm{~s}^{-1} / 2.10 \times 10^{-9} \mathrm{~m}^{2} \mathrm{~s}^{-1}=0.17$ ), close to the values 
Vol. 17 (2008): 252-264.

estimated by applying traditional diffusivity models to the water-filled soil volume (Simojoki 2000), and in the mid-range of values $0.02-0.5$ expected based on the diffusivities in dry soils (Stepniewski et al. 1994). However, much lower range of values $(0.003-0.15)$ have been measured in natural and model aggregates of soil by indirect methods (Currie 1979, Zausig and Horn 1992, Zausig et al. 1993).

We believe that our reported microdiffusivities are correct. However, some data were excluded as physically unrealistic (= implying higher diffusivities than those in water). In such cases, the diffusion is controlled by nearby air-filled pores rather than the liquid phase (Rappoldt 1995). This is more common in unsaturated soils compared with soils at or near saturation.

Notwithstanding the poor aeration properties, the soil produces crop yields considered normal. The contradiction is resolved by the fact that soil sampling for this study was carried out late in autumn. Thus, the measured values do not reflect summer conditions. Moreover, soil moisture is below the field capacity most of the growing period. Nevertheless, our results emphasize that successful crop growth in this soil probably depends very much on the annual loosening by tillage operations, as these effects are lost by next autumn.

The detrimental effects of conventional ploughing on the gaseous diffusivity in soil have been rare in the earlier studies where long-term conventional and reduced tillage have been compared. The beneficial effects of loosening the topsoil by ploughing are more commonly reported (Douglas and Goss 1987, Ball et al. 1994, 1997, Schjønning 1989), although it is clear that tillage operations disrupt the existing pore system in the topsoil and reduce their connections to the soil below the tilled layer. The pertinent literature on the topic does not however allow generalizations about the impact of reduced tillage, as the results depend in an ill-specified manner on soil type, sampling time, sampling depth and soil matric potential (Schjønning 1989, Schjønning and Rasmussen 2000). In addition, the spatial and temporal scales are important. Soil management practices may change soil aeration by affecting the continuity of macropores at spatial scales much larger compared with the small soil cores generally used for the determination of gas transport properties, such as in this study. However, the millimetre and centimetre scales are the most important for the supplying oxygen to plant roots (Simojoki 2001). The time-frame of continuous tillage practices is important, as soil structure and the functioning of pores change slowly and at different rates at different depths after the transition from conventional to conservation tillage (Horn 2004).

Relatively few significant differences were attributable to the tillage and compaction treatments, in line with the soil mechanical investigations carried out in the same field (Fazekas 2005). Old root channels and earthworm burrows partly masked the effects and produced much scatter in the data (Fazekas 2005). However, two effects were very pronounced in the wheeling studies: 1) subsoil horizons with a platy structure showed a defined anisotropy of hydraulic and mechanical properties, and 2) stresses exceeding the internal soil strength destroy the existing pore continuity (extent or isotropy) and create a denser and less permeable soil volume. This study supports the results from mechanical investigations that a single wheeling by a $35000 \mathrm{~kg}$ sugar-beet harvester exceeds the soil strength near field capacity down to $60 \mathrm{~cm}$ soil depth and causes increased subsoil compaction in both conventional and conservation tillage.

\section{The relationship between the gaseous diffusivity and water retention properties in soil}

The application of a soil-water characteristic coupled diffusivity model proved useful in analyzing the data, as we could apply our results on gaseous diffusivity to the more representative set of samples for which the water retention was known. For this aim, we modified the 3POE-vG model and calibrated it with measured data, because the original model seriously underestimated the data.

The estimates obtained this way rely on the assumption that the gaseous diffusivity depend on soil water retention parameters similarly in large 
Simojoki, A. et al. Gaseous diffusion in a loess soil

and small cylinders. This was not explicitly tested by measurements. The dependence of water-retention parameters on sample size can be attributed to the pronounced heterogeneity of pores which dominate the actual fluxes and the amount of conducting pores. Our results demonstrate that soilwater characteristic coupled diffusivity models are likely to give more accurate and reliable estimates on gaseous diffusivity compared with the older models based on air-filled and/or total porosities, when analyzing structurally variable data such as in this study.

In structured or managed soils, the flux measurements do not necessarily always have a close correlation with each other. The diffusivity models express the functional relationship between intensity (relative diffusivity) and capacity (porosity, air-filled porosity, degree of air-saturation) properties. In the model of this study, any soil structural change is reflected by the parameters $m$ and $X_{100}$. The term with the exponent $m$ accounts for the pore space geometry (tortuosity) in dry soil. The term with the exponent $\mathrm{X}_{100}$ accounts for the tortuosity as a function of water saturation.

The parameter $m$ used for the calibration of diffusivity model deserves a closer discussion. It has been interpreted as "a mean value for tortuosity" in various flow models (Moldrup et al. 1996), or as a factor for particle or pore shape in gaseous diffusivity studies (Currie 1970). Moldrup et al. (2005) used $\mathrm{m}=2$ (Buckingham model in dry soil), and showed that the power functions $\mathrm{m}=2$ and $\mathrm{m}$ $=2.5$ provided the upper and lower limits for most of their data. Other authors have given different estimates for m. Thus, Moldrup et al. (1996) suggested $\mathrm{m}=1.5$ as a best fit for their proposed diffusivity model, whereas the traditional Millington and Quirk models correspond to $\mathrm{m}=1.33$ in dry soil. According to Currie (1970), the value of $m$ in dry soil depends on the particle shape, being theoretically equal to 1.5 for spheres and larger for more complicated shapes. His measurements accorded with $m=2$ for soil crumbs and $m=10$ for plate-like vermiculate and mica. The estimates in the range 1.5-2 are in line with our results.

\section{Conclusions}

We showed that the topsoil of Stagnic Luvisol is generally characterized by a poor soil structure with limited air space and slow gas transport in both macro- and microscale at moisture contents near the field capacity. Moreover, our results suggest that ploughing and heavy wheeling are detrimental to soil aeration. The macrodiffusion of oxygen in the reduced tilled topsoil was higher than in the ploughed soil. Wheeling the soil with a heavy sugar beet harvester decreased the gaseous macrodiffusivity by about half at all soil depths studied. Overall, the results show that already a single wheeling near field capacity with heavy machinery may cause compaction and impair aeration deep into the subsoil, and support the view that reduced tillage improves soil structure and aeration compared with the transient benefits by mouldboard ploughing in the topsoil. Despite inherent limitations, a soil-water characteristic coupled diffusivity model with a sitespecific calibration proved useful in delineating the relationship between capacity and intensity variables determining gas transport in structured soils. More extensive empirical data with actual gas transport measurements are needed on the topic. In the future, the spatial scale and soil type aspects of structural development should be taken into a more detailed consideration.

Acknowledgements. The empirical part of this research was carried out during the post-doctoral research visit of Asko Simojoki to the Institute of Soil Science and Plant Nutrition at the Christian-Albrechts University, Kiel, Germany. We thank the Institute for Sugar Beet Research in Göttingen for the management of the experimental field, and the staff in the Institute of Soil Science and Plant Nutrition for technical help during various phases of the project. The financial support by the Academy of Finland for the visit is gratefully acknowledged (decision 205132 / 2003). 
Vol. 17 (2008): 252-264.

\section{References}

Ball, B.C., Harris, W. the late \& Burford, J.R. 1981. A laboratory method to measure gas diffusion and flow in soil and other porous materials. Journal of Soil Science 32:323-333.

Ball, B.C., Lang, R.W., Robertson, E.A.G. \& Franklin, M.F. 1994. Crop performance and soil conditions on imperfectly drained loams after 20-25 years of conventional tillage or direct drilling. Soil \& Tillage Research 31:97-118.

Ball, B.C. \& Smith, K.A. 2001. Gas movement and air-filled porosity. In: Smith, K.A. \& Mullins, C.E. (eds), Soil and Environmental Analysis. Physical Methods. 2nd edition. P. 499-538. Marcel Dekker, New York.

Ball, B.C., Campbell, D.J., Douglas, J.T., Henshall, J.K. \& O'Sullivan, M.F. 1997. Soil structural quality, compaction and land management. European Journal of Soil Science 48:593-601.

Choy, B. \& Reible, D.D. 2000. Diffusion Models of Environmental Transport. 208 p. CRC Press, Boca Raton, FL.

Currie, J.A. 1970. Movement of gases in soil respiration. In: Sorption and Transport Processes in Soils. S.C.I. Monograph 37: 152-171.

Currie, J.A. 1979. Rothamsted studies of soil structure IV. Porosity, gas diffusion and pore complexity in dry soil crumbs. Journal of Soil Science 30:441-452.

Dörner, J. \& Horn, R. 2006. Anisotropy of pore functions in structured Stagnic Luvisols in the Weichselian moraine region in N Germany. Journal of Plant Nutrition and Soil Science 169:213-220.

Douglas, J.T. \& Goss, M.J. 1987. Modification of porespace by tillage in two Stagnogley soils with contrasting management histories. Soil \& Tillage Research 10:303-317.

Fazekas, O. 2005. Bedeutung von Bodenstruktur und Wasserspannung als stabilisierende Kenngrößen gegen intensive mechanische Belastungen in einer Parabraunerde aus Löss unter Plug- und Mulchsaat (Importance of soil structure and matric potential for the stabilization of a Stagnic Luvisol in ploughing and no ploughing tillage systems. In German, English summary), Diss., Institut für Pflanzenernährung und Bodenkunde, Universität Kiel. Schriftenreihe Nr. 67. 170 p. Available on the Internet: http://e-diss.uni-kiel.de/diss_1548

Horn, R., van den Akker, J.J.H. \& Arvidsson, J. (eds.) 2000. Subsoil compaction. Distribution, processes and consequences. Advanced in Geoecology 32. Catena, Reiskirchen. $462 \mathrm{p}$.

Horn, R. 2004. Time dependence of soil mechanical properties and pore functions for arable soils. Soil Science Society of America Journal 68:1131-1137.

Horn, R., Fleige, H., Richter, F.-H., Czyz, E.A., Dexter, A., Diaz-Pereira, E., Dumitru, E., Enarche, R., Mayol, F., Rajkai, K., de la Rosa, D. \& Simota, C. 2005. SIDASS project. Part 5: Prediction of mechanical strength of arable soils and its effects on physical properties at various map scales. Soil \& Tillage Research 82:47-56.

Horn, R., Fleige H., Peth S. \& Peng X.H. (eds.) 2006. Soil Management for Sustainability. Advances in Geoecology 38. $497 \mathrm{p}$.
Kirby, J.M. 1991. The influence of soil deformation on the permeability to air. Journal of Soil Science 42:227-235.

Koch, H.-J., Stockfisch, N., Schäfer-Landefeld, L. \& Brandhuber, R. 2005. Response to the comment on "Effects of agricultural machinery with high axle load on soil properties of normally managed fields" (Authors L. Schäfer-Landefeld, R. Brandhuber, S. Fenner, H.-J. Koch \& N. Stockfisch, Soil \& Till. Res. 75:75-86) made by W.Ehlers, M.Goss, R.Horn. Soil \& Tillage Research 80:255-257.

Malicki, M. \& Walczak, R. 1983. A gauge of the redox potential and the oxygen diffusion rate in the soil with an automated regulation of cathode potential. Zeszyty Problemowe Postepow Nauk Rolniczych 220:457-461.

Marrero, T.R. \& Mason, E.A. 1972. Gaseous diffusion coefficients. Journal of Physical and Chemical Reference Data 1:3-118.

Moldrup, P., Kruse, C.W., Rolston, D.E. \& Yamaguchi, T. 1996. Modeling diffusion and reaction in soils: III. Predicting gas diffusivity from the Campbell soil-water retention model. Soil Science 161:366-375.

Moldrup, P., Olesen, T., Yoshikawa, S., Komatsu, T. \& Rolston, D.E. 2005. Predictive-descriptive models for gas and solute diffusion coefficients in variably saturated porous media coupled to pore-size distribution: II. Gas diffusivity in undisturbed soil. Soil Science 170:854-866.

Pagliai, M. \& Jones, R. (eds) 2002. Sustainable land management for environmental protection. A soil physical approach. Advances in Geoecology 35. Reiskirchen: Catena. $588 \mathrm{p}$.

Peth, S., Horn, R., Fazekas O. \& Richards B. 2006. Heavy soil loading and it consequences for soil structure, strength and deformation of arable soils. Journal of Plant Nutrition and Soil Science 169:775-783.

Rappoldt, C. 1995. Measuring the millimetre-scale oxygen diffusivity in soil using microelectrodes. European Journal of Soil Science 46:169-177.

Richards, B.G, Baumgartl, T. \& Horn, R. 2000: Modelling coupled processes in structured unsaturated soils. Theory and examples. In: Horn, R., van den Akker, J.H. \& Arvidsson J. (eds.). Subsoil Compaction - Distribution, Processes and Consequences. Advances in $\mathrm{Ge}$ oecology 32, p. 175-190.

Schäfer-Landefeld, L., Brandhuber, R., Fenner, S., Koch, H.-J. \& Stockfisch, N. 2004. Effects of agricultural machinery with high axle load on soil properties of normally managed fields. Soil \& Tillage Research 75:75-86.

Schjønning, P. 1989. Long-term reduced cultivation. II. Soil pore characteristics as shown by gas diffusivities and permeabilities and air-filled porosities. Soil \& Tillage Research 15:91-103.

Schjønning, P. \& Rasmussen, K.J. 2000. Soil strength and soil pore characteristics for direct drilled and ploughed soils. Soil \& Tillage Research 57:69-82.

Simojoki A. 2000. Responses of soil respiration and barley growth to modified supply of oxygen in the soil. Agricultural and Food Science in Finland 9: 303-318.

Simojoki, A. 2001. Oxygen supply to plant roots in cultivated mineral soils. Diss., Department of Applied Chemistry and Microbiology, University of Helsinki. Pro Terra 


\title{
AGRICULTURAL AND FOOD SCIENCE
}

Simojoki, A. et al. Gaseous diffusion in a loess soil

No. 7. Helsinki. 59 p. Available in Internet: http://ethesis.helsinki.fi

Soane, B.D. \& van Ouwerkerk, C. (eds.). 1994. Soil Compaction in Crop Production. Developments in Agricultural Engineering 11. Amsterdam: Elsevier. 662 p.

Stepniewski, W., Glinski, J. \& Ball, B.C. 1994. Effects of compaction on soil aeration properties. In: Soane, B.D. \& van Ouwerkerk, C. (eds.). Soil Compaction in Crop Production. Developments in Agricultural Engineering 11. Amsterdam: Elsevier. p. 167-189.
Van Genuchten, M. Th. 1980. A closed-form equation for predicting the hydraulic conductivity of unsaturated soils. Soil Science Society of America Journal 44:892-898.

Zausig, J. \& Horn, R. 1992. Soil water relations and aeration status of single soil aggregates, taken from a Gleyic Vertisol. Zeitschrift für Pflanzenernährung und Bodenkunde 155:237-245.

Zausig, J., Stepniewski, W. \& Horn, R. 1993. Oxygen concentration and redox potential gradients in unsaturated model soil aggregates. Soil Science Society of America Journal 57:908-916.

\section{SELOSTUS}

\section{Tiivistämisen ja kevennetyn muokkauksen vaikutus hapen makro- ja mikrodiffuusioon lössimaassa}

\author{
Asko Simojoki, Orsolya Fazekas-Becker ja Rainer Horn \\ Helsingin yliopisto ja Kielin yliopisto, Saksa
}

\begin{abstract}
Maatalouden koneellistuminen ja tehostuminen ovat lisänneet viljelymaiden tiivistymisen riskiä. Samanaikaisesti pyrkimykset energian säästämiseen, ympäristönäkökohtien huomioimiseen sekä kestävään ja hyvin toimivaan maan huokosrakenteeseen ovat johtaneet kevennettyjen maanmuokkaustapojen yleistymiseen. Tiivistäminen ja muokkaus vaikuttavat maan ilmavuuteen muuttamalla maan rakennetta ja helposti hajoavan eloperäisen aineksen määrää ja jakaantumaa. Maan kevennetyn muokkauksen ja perinteisen kynnön vaikutuksia kaasun liikkumiseen maan eri syvyyksillä tutkittiin $12 \mathrm{v}$ jatkuneessa maanmuokkauskokeessa (Sokerijuurikkaan tutkimuslaitos IfZ, Göttingen, Saksa) kentällä, jonka maannos (Stagnic Luvisol) osoitti siinä ilmenevän ajoittaista hapenpuutetta. Lisäksi tutkittiin $35000 \mathrm{~kg}$ painavan sokerijuurikkaankorjuukoneen yksittäisen ajokerran aiheuttaman maan tiivistymisen vaikutuksia näissä muokkauskäsittelyissä. Tarkoitusta varten otettiin syksyllä 2003 pintamaasta $(12 \mathrm{~cm}$ syvyydeltä), kyntöanturasta ( $35 \mathrm{~cm}$ syvyydeltä) ja syvältä
\end{abstract}

pohjamaasta $(60 \mathrm{~cm})$ rakennenäytteitä, joista mitattiin ilmatilan määrä, hapen makro- ja mikrodiffuusiokerroin, hapen diffuusionopeus ja ilmanläpäisevyys eri tavoitekosteuksissa.

Huonon rakenteen vuoksi pintamaan ilmatila oli pieni ja sen hapen makro- ja mikrodiffuusio hidasta lähellä kenttäkapasiteettia olevissa kosteuksissa. Kevennetysti muokatussa maassa hapen makrodiffuusio pintamaassa oli nopeampaa kuin kynnetyssä maassa. Maan tiivistäminen hidasti hapen diffuusiota noin puoleen tiivistämättömän maan arvoista kaikissa tutkituissa maan syvyyksissä. Tulokset osoittavat, että jo yksi ajokerta nykyaikaisella raskaalla korjuukoneella tiivistää maan rakennetta ja heikentää kaasun liikkumista sekä pintamaassa että syvällä pohjamaassa. Tulokset tukevat myös käsitystä kevennetyn muokkauksen edullisista vaikutuksista maan rakenteeseen ja ilmavuuteen, erityisesti maan pintakerroksissa. Aiheesta tarvitaan lisätutkimusta, jossa kiinnitetään erityishuomiota rakenteen kehittymiseen eri maalajeilla. 